\title{
The Integration of Soft Skills in English Language Teaching and Learning Through AL-ASPEM
}

\author{
Patcharobon Jariyathitinant \\ English Department,Shool of Liberal Arts, University of Phayao \\ napat9@ hotmail.com
}

\begin{abstract}
The purposes of this research were to develop the undergraduate students' in three domains; the results of Language proficiency mainly in speaking and listening on project presentation, students' competency (soft skills) in the 21 st century, and the satisfaction on Teaching and Learning by AL-ASPEM.

The AL-ASPEM is the integrated teaching process and developed under the Active learning (AL) and Problem-based learning (ASPEM) theories and principles. It focuses to develop students' language proficiency and the process of critical thinking during students' handling their project presentation. AL-ASPEM was implemented as English language teaching and learning with 94 students in University of Phayao, Thailand who registered in the 1st semester of 2020 for the 2 courses; English for specific purposes (ESP n=43) and English for communication (Eng.-Com n=51). Not only the English language proficiency especially in speaking and listening skills were developed and the soft skills (4CsMIT) refers 4Cs : critical thinking and problem-solving, creativity, communication and collaboration; in addition, MIT stands for media innovation and technology literacy could be enhanced.

Students' language proficiency was continually evaluated and graded by the 4 times of students' project presentation rubric scores as learning process through AL-ASPEM, and the quality of the products. While the $51.16 \%$ from ESP students' language proficiency was highest level and $48.83 \%$ was high level, the project quality was $100 \%$ excellent level. Otherwise, the 51 Eng.-Com students $78.43 \%$ was in highest level, $23.5 \%$ was in High level, and $1.9 \%$ was in moderate level of the learning process. But, the products quality showed that $50 \%$ was in the excellent level, and $50 \%$ was in good level.

Moreover, the correlation of students' competency (4CsMIT) in both the 21st century competency analysis and the developed critical thinking processes through AL-ASPEM found that in the high level in both groups of students; so that, ESP and Eng.-Com class had a positive correlated performance score. It tended to be significantly higher at the .01 level.

Finally, for the satisfaction on teaching and learning by AL-ASPEM was assessed under the unit contents, class activities, teaching aids, students project, and students' social skills. The results showed that all students form both ESP and Eng.-Com satisfied in high level. It tended to be significantly higher at the .01 level.
\end{abstract}

\section{Index Terms}

Soft Skills, Critical Thinking, Students' Competency in the 21st Century, English Active Learning, Integrated skills in English Language Teaching and Learning

Article Received: 10 August 2020, Revised: 25 October 2020, Accepted: 18 November 2020

\section{Introduction}

To develop the generation $\mathrm{Z}$ to live through a period of rapid change, an increasingly globalized environment, Innovation and technological advances, the researcher, as and English lecturer, constantly concerns about the changing of ways to communicate, work, and live together. For the further coming future, employers are agreed that the future workforce needs a basic set of professional skills and attitudes for long-term career success.

In the $21^{\text {st }}$ century, the value of the $21^{\text {st }}$ century education is the success which has been differently changed from the past. Driscoll (2016) [2] said the $21^{\text {st }}$ century students are in the Generation $\mathrm{Z}$ - born between 1995 and 2009 - They are able to teach themselves about any topic they are interested in without even leaving their bedroom. These generations have grown up with advanced technology as a given in their homes and classrooms. They are digital natives. Not only these young students in our schools today are intelligent, independent and extremely capable, they are skilled with technology and comfortable with global and intercultural communication.

According to Canadian Chamber of Commerce (2014) [3] , the soft skills are generally understood to include writing skills, oral communication skills, presentation skills, interpersonal skills, priority and goal setting, and lifelong learning skills. Weiner (2000) [4] defined soft skills can be classified into two personal skills; inter personal refer to individual's ability in managing himself for optimally developing works; for example, time management, stress management and creative thinking. Meanwhile, inter personal skills are defined as individual's skills in managing their relationship with others for optimal work developments, i.e.: ability to motivate, to lead and to negotiate. Soft skills for recent graduates include leadership skills, critical thinking and problem solving skills, information management skills, and entrepreneurship skills (Kee, Ahmad, Ibrahim, \& Nie, 2012) [5]

The conference board of Office of the Higher Education Commission. (2006) [6] claims four soft kills as most critical for future workers are 1.professionalism / work ethic 2.Oral and written communications 3.Teamwork / collaboration and 4.criticalthinking/ problem solving. Hence, the researcher as the $21^{\mathrm{st}}$ century lecturer is extremely interested for developing the process of English teaching process to practice students not only English language proficiency, but also inquiring soft skills for supporting their ethical professional career. 
The challenge for Thailand, how to transform teaching and learning emphasizing the development of student competencies and the application of learning and skills are the primary focus of education. According to the $2^{\text {nd }}$ decade of Thailand Education Reform [7], the curriculum itself is required, as the curriculum framework sets the vision for education and guides the learning objectives and outcomes expected of all students in the country. The process of curriculum reform should therefore be one which defines and responds to the knowledge, skills, attitudes and values young people will need to thrive in the world, not just today, but in the years to come. In addition, leaning assessment is also be reformed hand in hand with the introduction of a new curriculum and pedagogical approaches. While the current high-stakes national examinations have not been designed with a competency-based lens, competency assessments should be measure student's competencies and abilities to apply learning and can also incorporate project work conducted throughout the each semester in the whole year of education.

So that, the shift of teachers' role in this era teaching is to completely change from giving students all the knowledge and information to be supporting students as they make their own steps of enquiry knowledge in different fields. For preparing learning sources make sure that they have the skills to endeavor and totally get through it. Teaching and learning should help students along the way as they build confidence to achieve. This means teachers need to be forward-thinking, curious and flexible. Teachers must be learners: learning new ways of teaching, and learning alongside their students.

According to the Framework for 21st Century Learning, the Partnership for 21st Century Skills [8] indicates the core subject are English, reading or language arts, world languages, arts, mathematics, economics, science, geography, history, government and civics (Core Subjects). The necessary learning and innovation skills; such as, critical thinking, problem solving, communication and collaboration should be integrated into the teaching of core academic subjects. Moreover, Information, Media and Technology Skills which assists students to ascertain and update their worldwide information that their need to be acquired.

However, Higher Education, National Qualifications Framework for Higher Education in Thailand (2006) and also Thai Qualifications Framework for Higher Education (TQF: HEd) [9] indicates the domains of Learning for higher education. The domains are: 1) Ethical and Moral Development: Development of Habits of acting ethically and responsibly in personal and public life in ways that are consistent with high moral standards. And the Ability to resolve value conflicts through application of a consistent system of values. 2) Knowledge: the ability to understand, recall and present information including : Knowledge of specific facts, knowledge of concepts, principles and theories and knowledge of procedures. 3) Cognitive skills: the ability to apply knowledge and understanding of concepts, principles, theories and procedures when asked to do so; and Analyze situations and apply conceptual understanding of principles and theories in critical thinking and creative problem solving when faced with unanticipated new situations. 4) Interpersonal skills and Responsibility: the ability to work effectively in groups, and exercise leadership, accept personal and social responsibility, and plan and take responsibility for their own learning, and

5) Analytical and Communication skills: the ability to use basic mathematical and statistical techniques, communicate effectively in oral and written form, and use information and communications technology.

There are various terms used to describe active learning (AL) and these include AL is student- centered learning, collaborative learning (team, peer or group learning), engaged learning, and participatory learning. In terms of Haack (2008) [10], AL is generally as student - centered approach of learning. Significantly, students should be selfregulated and have an active role in decision making process while they are engaging in cognitively challenging academic tasks. Moreover, AL enhances the quality of student learning by creating meaning rather than memorizing information transmitted by the teacher. As in language assessment according to student- centered approaches, modes of assessment are to encourage the development of all four language skills (reading, writing, speaking and listening) and other alternatively to evaluate higher-order thinking skills as part of lifelong learning. Bonwell and Eison (1991)[11] defines strategies that promote AL as "instructional activities involving students in doing things and thinking about what they are doing". Moreover, students involved in higher-order thinking (analysis, synthesis, and evaluation), and greater emphasis is placed on exploration of their own attitudes and values. Cambridge Assessment International Education (2019) [12] informs that AL is an approach where learners participate in the learning process by building knowledge and understanding. It based on a theory of learning called constructivism, which emphasizes the fact that learners construct or build their understanding. AL builds both knowledge and understanding which students can then apply to new contexts and problems, and fosters students' learning and their autonomy, giving them greater involvement and control over their learning and giving them skills of life-long learning. Students are developed higher-order thinking skills to achieve high grades cause by AL approaches. New coming study have shown, AL is an approach encouraging a life long learning process and help students with their cognitive skills and soft skills (Demirci, 2017). [13] The soft skills encourage critical thinking, problem- solving and task based learning skills in an active AL environment. Some of the key themes identified in active learning were. Not only students involved in class activities more than listening but reading, discussing, or writing were significant roles.

Consequently, for the researcher AL is an approach that provides meaningful learning and learning how to learn. It gives students' opportunity to speak, listen, read, write and think. The content of the lesson is learned through activities, which have students practice the knowledge, such as problem solving, informal buzz groups, simulations, case studies, drama etc. For English class, active learning need to develop students' English skills and transmit require information from student's reading, discussing, writingthat requires higher-order thinking. They also tend to place some emphasis on students' explorations of their own attitudes and values. 
In order to achieve the target of learning Domain (HEd) and develop students' knowledge and the $21^{\text {st }}$ century skills (soft skills) as mentioned before. Moreover, as benefits for students' competency to work in their future career, the researcher would like to develop the process of active English language teaching and learning based on the applying active learning and problem-based learning as "AL-ASPEM". The developed AL-ASPEM as the process of English teaching process could help students to develop their learning and innovation Skills: (4Cs: Critical thinking and problem solving, Creatively and innovation, Communication and Collaboration) which are mainly essential four soft skills, and Information, Media \& Technology Skills (MIT) as "4CsMIT" as the $21^{\text {st }}$ century competency could be develop in English language classroom.

\section{Research Objectives}

The objectives of this research article were 1) to develop undergraduate students' competencies in the 21 st century (soft skills: 4CsMIT) 2) to achieve in their English language proficiency and 3) to study the satisfaction of students who study with AL-ASPEM

\section{Research Methods}

\section{A. Research Design}

The quantitative experimental research were used for implementing AL-ASPEM to find 3 domains, mentioned three objectives, with students who registered for 2 courses 146200 English for Specific Purposes (ESP) and 146131 English for Communication (Eng.-Com) in the $1^{\text {st }}$ semester of 2020 academic year, University of Phayao. Students who enrolled were evaluated by the course evaluation, to be graded for the English proficiency and only two parts of the course evaluation were counted for assessing students' soft skills (4CsMIT) as the $21^{\text {st }}$ century competency, which were project progress presentation (speaking and listening) and project, as the outcome of implementing AL-ASPEM (objective1). For the objective 2 , not only speaking and listening performance but also two tests were used as midterm and final summative assessment focusing on reading and writing ability. Consequently, the questionnaire as the tool of gathering data of satisfaction survey was use to figure out the admiration of the students who leant with ALASPEM (objective3)

For research instruments, the data collected tools of the soft skills (4Cs and MIT) as the 21 st century competency were checklist consisted of

1) The checklist of common thinking competency used to assess before and after learning with the AL-ASPEM

2) The checklist of initiated thinking process used to assess the launched critical thinking while learning with ALASPEM

3) The checklist of the 21 st century competency to assess the launched competency after learning with AL-ASPEM While, English language proficiency were 4 skills assessing which could be identified by theses research tool;

5) The Mid-term and Final Examination to assess student's reading and writing ability
6) The project progress presentation (process scoring) and Project (product scoring) which was be in line of the 4CsMIT rating for assessing students' speaking and listening performance

Finally, to gather students' satisfaction of learning with ALASPEM, the satisfaction survey was used.

7) The satisfaction survey of the implementation ALASPEM as active English teaching and learning

However, before conducting all research tools for checking the quality of research tools, all the experimental research tools; the English speaking rubric score, mid-term and final tests, the collected data tools; the 3 checklists, an questionnaire were checked by the 6 experts by the Index of Item objective, congruence (content validity). Considerably, data analysis were analyzed by Descriptive statistics; Mean, Percentage, S.D. and Pearson's correlation coefficient

\section{B. Research Process}

Research process of this research has developed into 7 steps consisted of 1) to study for review literature and related research, 2) design for experimental tools, 3) to check for the tools quality, 4) to conduct AL-ASPEM analyze, 5) to correct data, 6) to analyze data and 7) to do the research report. All steps were shown in Fig.1

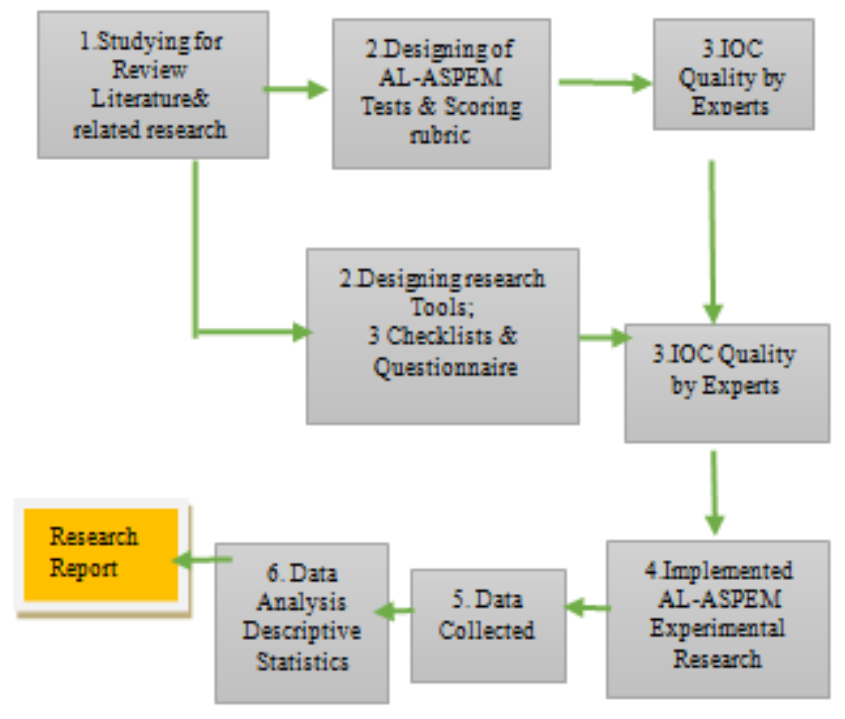

Fig.1 Research process for the Integration of Soft Skills in English Language Teaching and Learning through ALASPEM

AL-ASPEM as teaching process innovation developed under the theories and principles of AL and PBL. It can be indicated as the table below;

\begin{tabular}{|c|c|c|}
\hline \multirow{2}{*}{$\begin{array}{l}\text { AL-ASPEM } \\
\text { (Concept } \\
\text { Defining) }\end{array}$} & \multicolumn{2}{|c|}{$\begin{array}{l}\text { Expected Soft Skills (4CsMIT) } \\
\text { in the } 21^{\text {st }} \text { century }\end{array}$} \\
\hline & $\begin{array}{l}\text { Leaning and } \\
\text { Innovation } \\
\text { Skills } \\
\text { (4Cs) }\end{array}$ & $\begin{array}{l}\text { Information, } \\
\text { Media \& } \\
\text { Technology } \\
\text { Skills } \\
\text { (MIT) }\end{array}$ \\
\hline $\begin{array}{l}\text { Stage 1: } \\
\text { Analyzing: } \\
\text { Identify and } \\
\text { Classify what they } \\
\text { know or don't }\end{array}$ & $\begin{array}{l}\text { Critical } \\
\text { Thinking }\end{array}$ & $\begin{array}{l}\text { Information } \\
\text { Literacy+ Media } \\
\text { Literacy }\end{array}$ \\
\hline
\end{tabular}




\begin{tabular}{|c|c|c|}
\hline know & & \\
\hline $\begin{array}{ll}\text { Stage } & \text { 2: } \\
\text { Synthesizing: } & \\
\text { Rearrange } & \text { all } \\
\text { concepts from the } \\
\text { providing text }\end{array}$ & $\begin{array}{l}\text { Critical } \\
\text { Thinking }\end{array}$ & $\begin{array}{l}\text { Information } \\
\text { Literacy+ Media } \\
\text { Literacy }\end{array}$ \\
\hline $\begin{array}{l}\text { Stage 3: Problems } \\
\text { Solving: Inquiry } \\
\text { for Solving } \\
\text { PBL: Clarifying } \\
\text { unfamiliar terms, } \\
\text { Rules, and Concept } \\
\text { and set the issues } \\
\text { of further study } \\
\text { (new knowledge } \\
\text { and skills) }\end{array}$ & $\begin{array}{l}\text { Creativity and } \\
\text { Innovation }\end{array}$ & $\begin{array}{l}\text { Information } \\
\text { Literacy+ Media } \\
\text { Literacy }\end{array}$ \\
\hline $\begin{array}{l}\text { AL-ASPEM } \\
\text { (Concept }\end{array}$ & $\begin{array}{l}\text { Expected Soft } S \\
\text { in the } 21^{\text {st }} \text { centu }\end{array}$ & $\begin{array}{l}\text { ills (4CsMIT) } \\
\text { y }\end{array}$ \\
\hline Defining) & $\begin{array}{l}\text { Leaning and } \\
\text { Innovation } \\
\text { Skills } \\
(4 \mathrm{Cs})\end{array}$ & $\begin{array}{l}\text { Information, } \\
\text { Media } \\
\text { Technology } \\
\text { Skills } \\
\text { (MIT) }\end{array}$ \\
\hline $\begin{array}{l}\text { Stage 4: } \\
\text { Evaluation and } \\
\text { Making Decision: } \\
\text { Sharing Results } \\
\text { and Presentation of } \\
\text { Fomulating } \\
\text { learning issues } \\
\text { (new knowledge } \\
\text { and skills which } \\
\text { can help to design } \\
\text { contents of project } \\
\text { progress and } \\
\text { project) }\end{array}$ & Communication & $\begin{array}{l}\text { Information, } \\
\text { Communications } \\
\text { and Technology, } \\
\text { Literacy }\end{array}$ \\
\hline $\begin{array}{l}\text { Stage 5: Making } \\
\text { Resolution: } \\
\text { Presenting the } \\
\text { project and project } \\
\text { progress }\end{array}$ & $\begin{array}{l}\text { Communication } \\
\text { and } \\
\text { Collaboration }\end{array}$ & $\begin{array}{l}\text { Information, } \\
\text { Communications } \\
\text { and Technology, } \\
\text { Literacy }\end{array}$ \\
\hline
\end{tabular}

Table1: The 5 stages of AL-ASPEM promoting language proficiency and 4CsMIT

\section{Results}

To implementation AL-ASPEM the active English teaching and learning in English class, the undergraduate students are able to...

1) To develop undergraduate students' soft skills (the competency in the 21 st century), there was 3 checklist to analyze as below,

1.1 The checklist of initiated thinking process used to assess the launched critical thinking while learning with ALASPEM

This checklist was used to analyze the critical thinking occurred by implementation through out the 5 steps of AL-
ASPEM in class while students doing activities and doing project. The essential critical thinking process by 5 steps systematically: 1.7 items of analyzing 2. 6 items of synthesizing 3. 13 items of critical thinking 4.6 items of creativity. The results of collected data were as below,

\begin{tabular}{|c|c|c|c|c|c|c|}
\hline \multirow[b]{2}{*}{$\begin{array}{l}\text { Critical } \\
\text { thinking }\end{array}$} & \multicolumn{3}{|l|}{ ESP } & \multicolumn{3}{|c|}{ ENG.-Com } \\
\hline & Mean & S.D. & Level & Mean & S.D. & Level \\
\hline $\begin{array}{l}\text { Step 1: } \\
\text { Analyzing }\end{array}$ & 3.69 & 0.73 & high & 3.48 & 0.70 & moderate \\
\hline $\begin{array}{l}\text { Step 2: } \\
\text { Synthesizing }\end{array}$ & 3.77 & 0.75 & high & 3.72 & 0.74 & high \\
\hline $\begin{array}{l}\text { Step } 3: \\
\text { Critical } \\
\text { thinking }\end{array}$ & 3.77 & 0.75 & high & 3.47 & 0.72 & moderate \\
\hline $\begin{array}{ll}\text { Step } & 4: \\
\text { Critical } & \\
\text { thinking } & \\
\end{array}$ & 3.91 & 0.84 & high & 3.60 & 0.82 & high \\
\hline $\begin{array}{ll}\text { Step } & 5: \\
\text { Creativity }\end{array}$ & 3.85 & 0.72 & high & 3.46 & 0.71 & moderate \\
\hline Total & 3.75 & 0.77 & high & 3.54 & 0.74 & high \\
\hline
\end{tabular}

Table2: The level of 4Cs after studying each step with ALASPEM

As can been seen that the ESP students' critical thinking were high level which different from Eng.-com students, that was 2 times of project progresses and projects were perform while Eng.-com students was only one times assessed. It would assume that more times practicing, more student's progress and development in English proficiency, and absolutely for more developing critical thinking skills. 1.2 The checklist of the $21 \mathrm{st}$ century competency (soft skills) to assess the launched competency after learning with AL-ASPEM

The students' expected $21^{\text {st }}$ competency would be develop while learning with Al-ASPEM were 5 items of communication, 5 items of thinking critically, 5 items of problem- solving skills, 5 items of life skills, and 5 items of media and technology skills.

\begin{tabular}{|l|c|c|c|c|c|c|}
\hline \multirow{2}{*}{$\begin{array}{c}\text { The students' } \\
\text { expected 21st } \\
\begin{array}{c}\text { competency } \\
\text { (Soft Skills) }\end{array}\end{array}$} & \multicolumn{3}{|c|}{ ESP } & \multicolumn{3}{|c|}{ Eng.-Com } \\
\cline { 2 - 7 } & Mean & S.D. & Level & Mean & S.D. & Level \\
\hline Communication & 2.17 & 0.58 & moderate & 2.09 & 0.61 & moderate \\
\hline $\begin{array}{l}\text { Thinking } \\
\text { critically }\end{array}$ & 2.23 & 0.61 & moderate & 1.99 & 0.53 & moderate \\
\hline $\begin{array}{l}\text { Problem- solving } \\
\text { skills }\end{array}$ & 2.23 & 0.61 & moderate & 2.23 & 0.72 & moderate \\
\hline Life skills & 2.17 & 0.52 & moderate & 2.05 & 0.51 & moderate \\
\hline $\begin{array}{l}\text { Media and } \\
\text { technology skills }\end{array}$ & 2.24 & 0.65 & moderate & 2.06 & 0.66 & moderate \\
\hline \multicolumn{1}{|c|}{ Total } & $\mathbf{2 . 2 4}$ & $\mathbf{0 . 6}$ & moderate & $\mathbf{2 . 0 8}$ & $\mathbf{0 . 6 0}$ & moderate \\
\hline
\end{tabular}

Table3: The level of 4CsMIT from project presentation and project after studying with AL-ASPEM

Throughout the project progress and the final presentation of the project, students from both classes work hard for developing their project. The best project would be the best model for another to develop their tasks. ESP program did two times, but Eng.-Com did only one time. From the table 2 , it could criticize that students assessed themselves in moderate level, they tended to need time to develop more. However, to analyze with Pearson's correlation coefficient, both group of students tended to be in positive level in both the initiated critical thinking process and the students' expected 21st competency (soft skills) while learning with AL-ASPEM showing by the analyzing from table 3 below, 


\begin{tabular}{|c|c|c|c|c|}
\hline $\begin{array}{l}\text { The Correlation } \\
\text { among }\end{array}$ & Group & Mean & S.D. & $\mathbf{r}_{\mathrm{xy}}$ \\
\hline \multirow{2}{*}{$\begin{array}{lr}\text { The } & \text { students' } \\
\text { expected } & 21 \mathrm{st} \\
\text { competency } & \text { (soft } \\
\text { skills) } & \\
\end{array}$} & ESP & 2.26 & 0.60 & \multirow[b]{2}{*}{$0.753 * *$} \\
\hline & $\begin{array}{l}\text { Eng- } \\
\text { Com }\end{array}$ & 2.08 & 0.60 & \\
\hline \multirow{2}{*}{$\begin{array}{ll}\text { The } & \text { initiated } \\
\text { critical } & \text { thinking } \\
\text { process } & \end{array}$} & ESP & 3.75 & 0.77 & \multirow[b]{2}{*}{$0.825 * *$} \\
\hline & $\begin{array}{l}\text { Eng- } \\
\text { Com }\end{array}$ & 3.54 & 0.74 & \\
\hline
\end{tabular}

** significant 0.01

Table4: The correlation among the 4CsMIT (students' expected 21 st competency) and the initiated critical thinking process from studying with AL-ASPEM

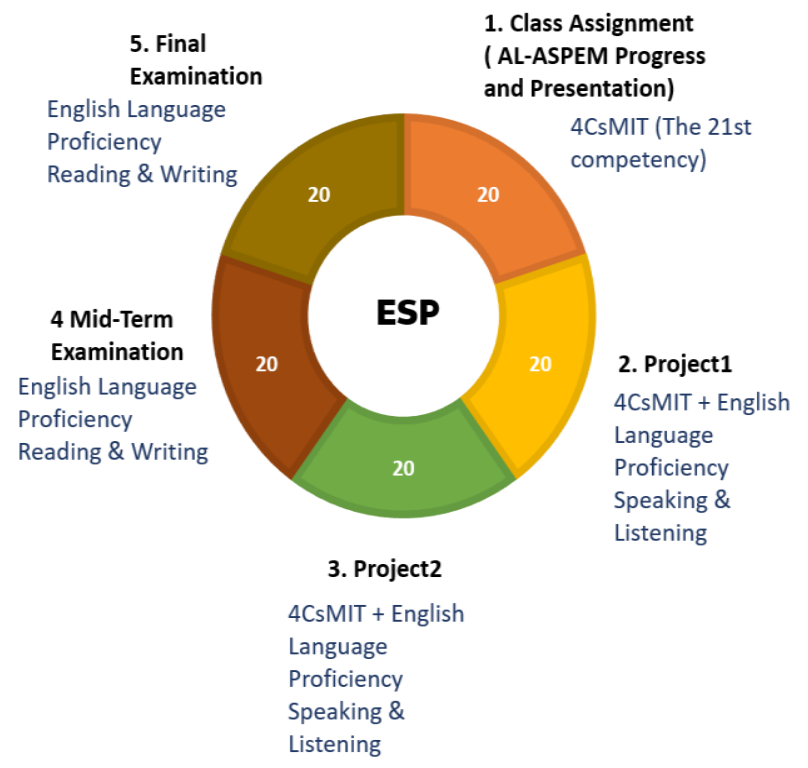

2) To achieve in their English language proficiency.

According to the course syllabus and course evaluation, ESP subject which was handled by the researcher oneself; while Eng.-Com were team teaching. However, the formats of the course assessment tasks were divided into 1) the project progress presentation and project (No. 1, 2,and 3) used to assess speaking and listening performance 2) the tests: midterm and final examination used to assess students' reading and writing ability. However, the consistent of course valuation was in line of the formats of research objectives assessment as the Fig. 2 below,

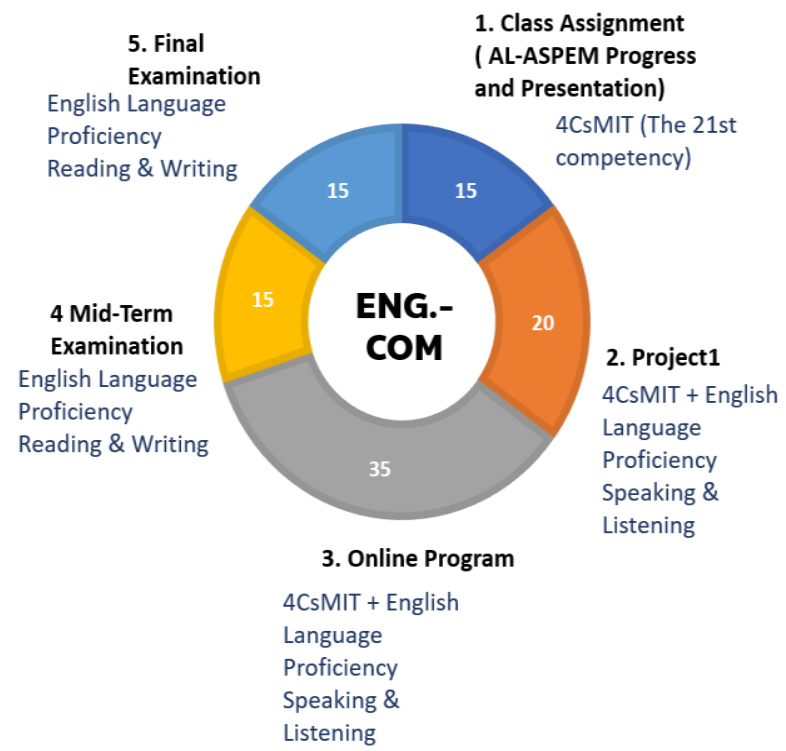

Fig. 2 The percentage of course evaluation tasks on English language proficiency and 4CsMIT (the $21^{\text {st }}$ century competency) in both courses: ESP and Eng.-Com

As a results of course grading $9(\mathrm{~A}, \mathrm{~B}+, \mathrm{B}, \mathrm{C}+, \mathrm{C}, \mathrm{D}+$,

$\mathrm{F}$ ), it could be inferred that score of the project progress presentation and the project grading supported students achieve in the high grading which were $\mathrm{A}, \mathrm{B}+, \mathrm{B}$. Both

kinds of assessment (No.1, 2 and 3 in Fig.2) indicatned that the integrated AL-ASPEM supported ESP $(n=43)$ group acquired gained high grading $74.41 \%$, when Eng.-Com $(n=51)$ obtained $78.43 \%$ and all students $(n=94)$ achieved $76.59 \%$.

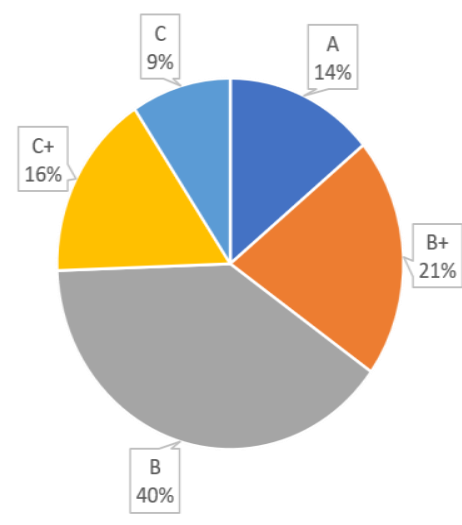

ESP

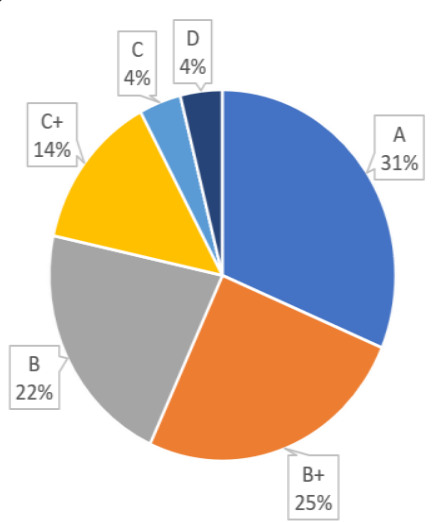

ENG.-COM

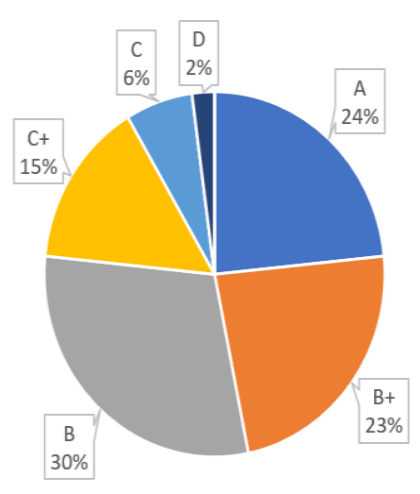

TOTAL

Fig.3 The percentage of course evaluation grading in both courses: ESP and Eng.-Com

Moreover, in the detailed criticizing consideration of the project progress presentation (process scoring) and project (project scoring), both process and product referred to students' speaking performance and project quality. It could explain that from the interval scales according to the rubric criteria the excellent and good level of process and product performed by both ESP and Eng.-Com, while the product 
were totally excellent from ESP, the Eng.-Com were in

\section{Project Progress by AL-ASPEM (Process Scoring)}
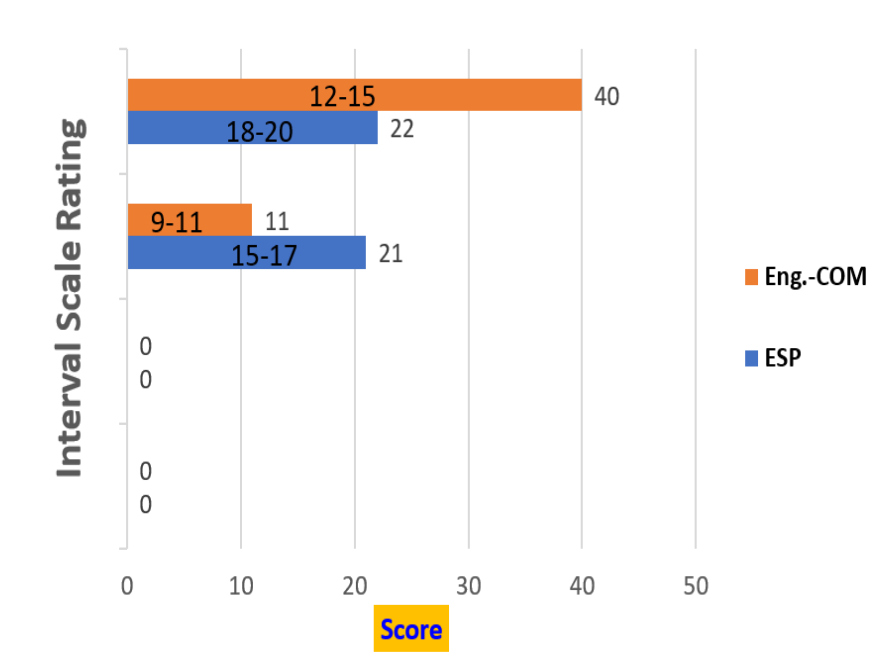

excellent and good level by the Fig. 4 below,

\section{Level of Quality}

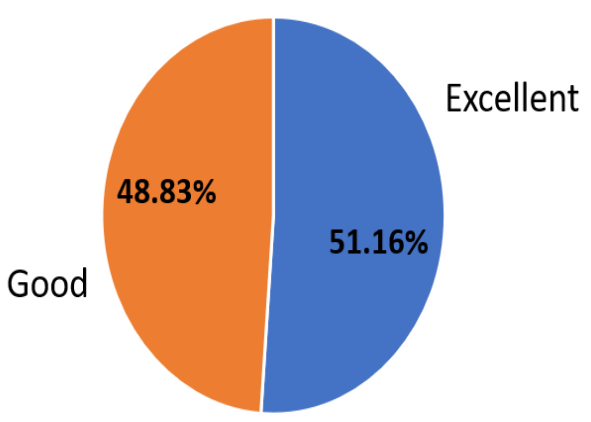

$\square$ ESP ENG.-COM

Fig.4 The interval scales of the level of students' score from project progress presentation and project in both courses: ESP and Eng.-Com

3) To study the satisfaction of students who study with ALASPEM

The satisfaction survey is the 35 items of questionnaire, which detailed in 5 topics of the AL-ASPEM implementation: the 6 items of unit contents, 13 items of class activities which shift from class activities to completely online class, 9 items of teaching materials and students project and the 7 items of social skills.

\begin{tabular}{|c|c|c|c|c|c|c|}
\hline \multirow{2}{*}{$\begin{array}{l}\text { The } \\
\text { satisfactio } \\
\text { n of } \\
\text { Learning } \\
\text { with AL- } \\
\text { ASPEM }\end{array}$} & \multicolumn{3}{|l|}{ ESP } & \multicolumn{3}{|c|}{ Eng.-Com } \\
\hline & $\begin{array}{l}\text { Mea } \\
\text { n }\end{array}$ & S.D & $\begin{array}{l}\text { Leve } \\
1\end{array}$ & $\begin{array}{l}\text { Mea } \\
\text { n }\end{array}$ & S.D & $\begin{array}{l}\text { Leve } \\
\text { l }\end{array}$ \\
\hline $\begin{array}{l}\text { 1. Unit } \\
\text { contents }\end{array}$ & 3.87 & 0.65 & high & 3.90 & 0.70 & high \\
\hline $\begin{array}{l}\text { 2.Class } \\
\text { activities } \\
\text { (online } \\
\text { teaching } \\
\text { and } \\
\text { learning ) } \\
\end{array}$ & 3.72 & 0.75 & high & 3.76 & 0.85 & high \\
\hline $\begin{array}{l}\text { 3.Teaching } \\
\text { materials } \\
\text { and } \\
\text { student's } \\
\text { project }\end{array}$ & 3.95 & 0.60 & high & 3.85 & 0.61 & high \\
\hline $\begin{array}{l}\text { 4.Social } \\
\text { skills }\end{array}$ & 4.25 & 0.78 & high & 4.09 & 0.76 & high \\
\hline Total & 3.91 & 0.72 & high & 3.88 & 0.77 & high \\
\hline
\end{tabular}

Table5: The satisfaction of learning with AL-ASPEM

Although the paradigm has been changed since the beginning of 2020, Education, teaching and learning have progressed for learner themselves 4 knowledge, cognitive skills, interpersonal skills and responsibility, analytical and Communication skills (Higher Education, National Qualifications Framework for Higher Education in Thailand
(HEd:2006) and also Thai Qualifications Framework for Higher Education (TQF). So that, as students admiration of AL-ASPEM in high level, the conducting of AL-ASPEM in University of Phayao would help students develop 4 from 5 domains of learning for higher education level.

\section{Recommendations}

\section{A. Recommendations for Practices}

From the results of data analyzing and according to AL-ASPEM, the researcher convince that in terms of integration of "4Cs" as students' learning and innovation concluded with information and media technology are coincided throughout the process of AL- ASPEM. The 4CsMIT (soft skills) is prominently integrated and revised across all curriculum mapping and strategic planning. While, the first " $C$ " as Critical thinking is about analyzing information and critiquing claims. The later " $C$ ": Communication is well enough to understand things and share clearly with other members in a group. The next third "C", Collaboration is about teamwork and the collective information, idea and opinion of a group to sum up what they have required and learned. For the last "C", Creativity is about thinking through information in new ways, making new connections and coming up with innovative solutions to problems. These skills are often referred to as transferrable skills as they can be used in different scenarios and across different domains, reflecting the growing trend that students will move across and between different areas of work during their careers where their ability to transfer skill-sets to meet new challenges will be tested.

Although the perform of conducting of AL-ASPEM was successful because of the researcher conducted from two classes of 2 courses in the same semester of academic year; moreover, the differences of two times showed the effectiveness results rather than once. However, researcher would like to see more about the progress of students' selfdirected learning. While students were struggling to be successful on project, are they recorded their self- reflection 
or self-esteem on their learning. Despite they were success on their tasks and the course, students themselves were happy to learn by doing or do they felt depress or stress on doing projects. If the process of AL-ASPEM could help students to criticize themselves on their progress and language learning, it would be support students to learn with happiness for a life- long learning person.

\section{B. Recommendations for Further Research}

For the next research, AL-ASPEM as an integrated teaching innovation to enhance 4CsMIT; consequently, the researcher would like to recommend this active English teaching and learning process in another subject field or level of education because of its integrated another skills (4CsMIT). Nevertheless, the researcher would like to use AL-ASPEM for further research on

1. AL-ASPEM could use for developing student's growth mindset.

2. AL-ASPEM could use for developing the another subjects or English curriculum

3. AL-ASPEM could use for promoting on teaching profession.

\section{Conclusion}

In conclusion, after practicing for a period of 4 months, the findings from the analysis of both quantitative showed that the development in the $21^{\text {st }}$ century (soft skills) were in high level in both students from two courses. Both group of students tended to be in positive level in both the initiated critical thinking process and the students' expected $21 \mathrm{st}$ competency while learning with AL-ASPEM. While, the level of critical thinking was developed, the 4CsMIT as the outcome from project presentation and project after studying with AL-ASPEM were moderate level form their own assessment. Nevertheless, students satisfied to learn and do the project in high level. The satisfaction toward ALASPEM were in high level.

Normally, the achievement on English language focuses on language ability (knowledge) and performance (skills), and the tests usually use to assess language ability. The process of AL-ASPEM which focused on the ability to present the project progress in English; in addition, the quality of using technology and program such as making video clip presentation were combined for creative English presentation performance and the quality of the project itself. For this research, tests was used to assess reading and writing skills, while speaking and listening were assessed by language presentation with students' performing by themselves. As the course evaluation, students preformed 76.59\% for B, B+ and A grading, and $21.27 \%$ for C, and C+ level. Only $2.12 \%$ performed in D level. As a result, ALASPEM could enhance in all four skills language proficiency. Interestingly, as for integrated critical thinking skills and MIT skills could promote students in English course systematically which presented by the project progress presentation and the quality of the delivered projects

\section{References}

[1] M. Driscoll, "Education in the 21st century" Retriveved September 25, 2019 from

https://thinkstrategicforschools.com/educat ion-21st-century/, 2016.

[2] Canada West Foundation, "Talent is not enough: Closing the skills gap"Retrieved November $\quad 1, \quad 2019$ from http://cwf.ca/pdfdocs/publications/CWF\% 20HC\%20Hire\%20Talent\%20Report\%20v 8.pd, 2014.

[3] B. Weiner, "Intrapersonal and Interpersonal Theories of Motivation from an Attributional Perspective", Educational Psychology Review, pp. 1-14, 2000.

[4] P. Kee, F. Ahmad, F. Ibrahim , \& S. Nie, “ Correlating Graduate Marketability Dimensions with the Measurements of University-Student Relationship. Asian Social Science, 8(6), p63, 2012.

[5] Office of the Higher Education Commission, "National Qualifications Framework for Higher Education in Thailand Implementation Handbook" Retrieved March 02, 2014 From http://www.mua.go.th/users/tqfhed/news/F ilesNews/FilesNews8/NQF-HEd.pdf, 2006.

[6] Office of the Basic Education Commission, " Basic education core curriculum B.E. 2551 (A.D. 2008)" Bangkok: Ministry of Education, 2008.

[7] Partnership for 21st Century Skills , “ Framework for Twenty-First Century Learning", https://www.teacherrambo.com/file.php/1/ 21st_century_skills.pdf, 2009.

[8] Office of the Higher Education Commission, " National Qualifications Framework for Higher Education in Thailand Implementation Handbook" Retrieved March 02, 2014 From http://www.mua.go.th/users/tgfhed/news/F ilesNews/FilesNews8/NQF-HEd.pdf, 2006. 
[9] Haack,K. (2008). "UN Studies and the Curriculum as Active Learning Tool" International Studies Perspectives, 9, 395410, 2008.

[10] C. Bonwell, A. Eison, A. "Active learning: creating excitement in the classroom." ASH\#-ERIC Higher Education Report No. 1,Washington, D.C.: The George Washington University, School of Education and Human Development, 1991

[11] Cambridge Assessment International Education. Implementing the Curriculum with Cambridge: A Guide for School Leaders. Retrieved September 21, 2019 from

https://www.cambridgeinternational.org/i mages/134557-implementing-thecurriculum-with-cambridge.pdf, 2019.

[12] C. Demirci," The effect of active learning approach on attitudes of 7th Grade students". International Journal of Instruction, 10(4), 129-144.2017 